Check for updates

Cite this: RSC Adv., 2020, 10, 42596

Received 21st October 2020

Accepted 16th November 2020

DOI: $10.1039 / \mathrm{d}$ Ora08969a

rsc.li/rsc-advances

\title{
Influence of the acid-base stoichiometry and residual water on the transport mechanism in a highly-Brønsted-acidic proton-conducting ionic liquid
}

\begin{abstract}
Jingjing Lin (1D ab and Carsten Korte (D) *ab
In this study, Brønsted-acidic proton conducting ionic liquids are considered as potential new electrolytes for polymer membrane fuel cells with operating temperatures above $100{ }^{\circ} \mathrm{C}$. N-Methyltaurine and trifluoromethanesulfonic acid $(\mathrm{TfOH})$ were mixed at various stoichiometric ratios in order to investigate the influence of an acid or base excess. The proton conductivity and self-diffusion of the "neat" and with $6 \mathrm{wt} \%$ water samples were investigated by following electrochemical and NMR methods. The composition change in the complete species and the relative proton transport mechanism based on the NMR results are discussed in detail. During fuel cell operation, the presence of significant amounts of residual water is unavoidable. In PEFC electrolytes, the predominating proton transfer process depends on the cooperative mechanism, when PILs are fixed on the polymer matrix within the membrane. Due to the comparable acidity of the cation $\left[2-\mathrm{Sema}^{+}\right.$and the hydroxonium cation, with excess $\mathrm{N}$ methyltaurine or $\mathrm{H}_{2} \mathrm{O}$ in the compositions, fast proton exchange reactions between the protonated [2Semal ${ }^{+}$cation, $\mathrm{N}$-methyltaurine and $\mathrm{H}_{2} \mathrm{O}$ can be envisaged. Thus, an increasing ratio of cooperative proton transport could be observed. Therefore, for polymer membrane fuel cells operating at elevated temperatures, the highly acidic PILs with excess bases are promising candidates for future use as electrolytes.
\end{abstract}

\section{Introduction}

Polymer electrolyte fuel cells (PEFCs) operating at elevated temperatures $\left(>100^{\circ} \mathrm{C}\right)$ offer significant improvements over lowtemperature PEFCs, such as no humidification of the feed gas, no water recirculation, a more efficient cooling of the cell and a higher tolerance against feed gas impurities..$^{1-3}$ The proton conductivity of NAFION ${ }^{\circledR}$-based proton exchange membranes (PEMs), used in PEFCs for low operation temperatures, depends mainly on the polymer's water uptake. For operation at elevated temperatures $\left(>100{ }^{\circ} \mathrm{C}\right)$, the conductivity of a new membrane material should be maintained in anhydrous conditions. Currently, (high temperature-) HT-PEFCs are based on polybenzimidazole (PBI) membranes doped with phosphoric acid $\left(\mathrm{H}_{3} \mathrm{PO}_{4}\right)^{4}{ }^{4-7}$ However, the presence of $\mathrm{H}_{3} \mathrm{PO}_{4}$ leads to slow cathodic oxygen reduction reaction (ORR) kinetics. ${ }^{8}$ There is a specific adsorption of $\mathrm{H}_{3} \mathrm{PO}_{4}$ species on active sites in the redox catalyst platinum, which causes an inhibition (poisoning) effect.9,10 In addition, the insufficient solubility and diffusivity

${ }^{a}$ Forschungszentrum Jülich GmbH, Institute of Energy and Climate Research - Fuel Cells (IEK-14), Wilhelm-Johnen-Straße, 52425 Jülich, Germany. E-mail: c.korte@ fz-juelich.de

${ }^{b}$ RWTH Aachen University, 52062 Aachen, Germany of oxygen is discussed. ${ }^{11}$ Thus, there is a need for new nonaqueous proton-conducting electrolytes to be operational for temperatures of $100-120^{\circ} \mathrm{C}$.

Proton-conducting ionic liquids (PILs) are promising candidates as non-aqueous electrolytes at operating temperatures $>100{ }^{\circ} \mathrm{C}$. Ionic liquids (ILs) are ionic compounds with bulky cations and anions and thus a low lattice energy. ${ }^{12}$ PILs have received much attention as a potential electrolyte in PEFCs due to their good conductivity, wide electrochemical windows and low flammability. ${ }^{13-18}$ In a PIL, the cation or anion may act as a protonic charge carrier, and so either the cations or anions are Brønsted-acids. In the case of cations, i.e., a PIL of the type $\mathrm{HB}^{+} \mathrm{A}^{-}$, it consists of an (organic) base $\mathrm{B}$, protonated by a very strong acid HA, respectively a super acid:

$$
\mathrm{B}+\mathrm{HA} \rightleftarrows \mathrm{HB}^{+}+\mathrm{A}^{-}
$$

The anions of super acids, such as trifluoromethanesulfonic acid or bis-trifluoromethylsulfonimid, have a less inhibiting effect on electrocatalytically-active electrode surfaces than $\mathrm{H}_{3} \mathrm{PO}_{4}$. The triflimid $\left(\mathrm{CF}_{3} \mathrm{SO}_{2}\right)_{2} \mathrm{~N}^{-}$and triflate $\mathrm{CF}_{3} \mathrm{SO}_{3}{ }^{-}$anions interact only very weakly with metal atoms, resulting in weak adsorption on a Pt surface. ${ }^{9,19,20}$ In a water-free PIL of the type $\mathrm{HB}^{+} \mathrm{A}^{-}$, protons can only move in an electric field via the 
protonated cations $\mathrm{HB}^{+}$by means of a vehicle mechanism. A drawback of ILs or PILs is often poor conductivity because of relatively high viscosity. A proton transfer back to the anion of the superacid, e.g., [TfO $]^{-}$, has only a very small probability because the protolysis equilibrium in eqn (1) is on the far right side. Thus, a cooperative transport mechanism involving the anions is not possible. In the case of vehicular mechanism, conductivity and viscosity are coupled to each other according to the Stokes-Einstein relation.

However, to avoid the leakage of the liquid electrolyte during operation, a PIL applied in a PEFC must be immobilized in a polymer matrix. A study of a [Dema][TfO]-doped PBI membrane by Liu et al. shows an activation energy of the conductivity in the range of the cooperative mechanism, ${ }^{21}$ whereas the pure [Dema][TfO] is vehicular. ${ }^{22}$ In this case, the vehicular transport of the cation $\mathrm{HB}^{+}$is constrained and a cooperative proton transport mechanism would be advantageous. This was shown in a study by Noda $e t$ al. that the excess in the base $\mathrm{B}$ of a PIL of the type $\mathrm{HB}^{+} \mathrm{A}^{-}$, which provides the cooperative proton transport and improves conductivity. ${ }^{12}$ The excess base $\mathrm{B}$ acts as a proton acceptor that is protonated by the proton donor $\mathrm{HB}^{+}$. The cooperative transports through the excess base $\mathrm{B}$ only necessitate the reorientations of the involved particles $\mathrm{B}$ an $\mathrm{HB}^{+}$. This results in increased proton conductivity and reduced activation energy for the conduction process. ${ }^{12,23,24}$ In particular, PILs contain strong Brønsted-acidic cations that are usually highly hygroscopic. The water absorption is difficult to prevent. Moreover, under fuel cell operation, water will be generated on the cathode side. The presence of residual water acts as a proton acceptor and gives rise to a protolysis equilibrium with the cation $\mathrm{HB}^{+}$:

$$
\mathrm{HB}^{+}+\mathrm{H}_{2} \mathrm{O} \rightleftarrows \mathrm{B}+\mathrm{H}_{3} \mathrm{O}^{+}
$$

Its extent depends on the acidity of the cation. In a preceding NMR study, it was shown that in Brønsted-acidic PILs of the type $\mathrm{HB}^{+} \mathrm{A}^{-}$cooperative proton transfer will dominate, depending on the cation acidity and the residual water content..$^{25}$ There will also be fast exchange between $\mathrm{HB}^{+}, \mathrm{B}, \mathrm{H}_{2} \mathrm{O}$ and $\mathrm{H}_{3} \mathrm{O}^{+}$. In general, as discussed above, the introduction of a proton acceptor would improve the cooperative transport. The coexistence of excess base B and residual water offer the possibility to improve the technically utilizable conductivity of PIL electrolytes.

In this experimental study, the effect of the PIL acid-base stoichiometry on the proton transport mechanism in a system with residual water is investigated. In general, cooperative proton transport in an IL system requires the presence of a proton acceptor and proton donor with comparable acidity. ${ }^{26} \mathrm{~A}$ highly acidic PIL, 2-sulfoethylmethylammonum triflate [2-Sema][TfO] $\left(\mathrm{p} K_{\mathrm{A} 1} \approx-1\right),{ }^{27}$ is used. The acidity of this is comparable to the hydroxonium cation $\left(\mathrm{p} K_{\mathrm{A}}=0\right)$. The 2-sulfoethylmethylammonium cation is prepared by means of the protonation of 2-methylaminoethanesulfonic acid ( $N$-methyltaurine), which exists as a zwitterion due to tautomerism. Because of the presence of the sulfonic acid functionality, it is a very strong acid that can protonate the residual water at a significant percentage. ${ }^{8}$
Appropriate amounts of $\mathrm{N}$-methyltaurine (MTau) and trifluoromethanesulfonic acid (TfOH) are mixed at various molar ratios to vary the PILs compositions from the TfOH-excess to MTau-excess. The interactions between the cations, the excess base and $\mathrm{H}_{2} \mathrm{O}$ are determined by means of electrical conductivity measurements and ${ }^{1} \mathrm{H}$ NMR spectroscopy. Using a pulsedfield gradient (PFG-) NMR technique, the self-diffusion coefficients of the individual protons in the PILs are obtained. The effect of stoichiometry and residual $\mathrm{H}_{2} \mathrm{O}$ on the prevailing proton transport mechanism ${ }^{26}$ is discussed by comparing the measured macroscopic and microscopic properties.

\section{Experimental}

\section{Materials}

Equimolar 2-sulfoethylmethylammonum triflate [2-Sema][TfO] is prepared by slowly adding trifluoromethanesulfonic acid (triflic acid, reagent grade: 98\%, Sigma Aldrich) to 2-methylaminoethanesulfonic acid ( $N$-methyltaurine, $\geq 99 \%$, Sigma Life Science). In the following, $N$-methyltaurine is abbreviated as MTau in analogy to triflic acid (TfOH). The total amount of [2-Sema][TfO] is divided into 5 bottles, each of about $5 \mathrm{~g}$. Appropriate amounts of TfOH and $N$-methyltaurine are added to each bottle to maintain the defined molar ratios $x$, i.e., $x[\mathrm{MTau}] \cdot(1-x)[\mathrm{TfOH}]$. The mole fraction of $N$-methyltaurine was from $x=0.3-0.7$. Thus, after mixing and heating samples with the composition $x$ [2-Sema] [TfO] $\cdot(1-2 x)[\mathrm{TfOH}]$ for $x=0.3-0.5$ and with the composition $(1-x)[2-\mathrm{Sema}][\mathrm{TfO}] \cdot(2 x-1)[\mathrm{MTau}]$ for $x=0.5-0.7$ are obtained.

Using Karl-Fischer titration, it can be observed that the samples prepared from the starting materials have a water content of $0.75-0.8 \mathrm{wt} \%$. To analyze the water content, two series of samples were investigated. The first series were the asprepared (neat) $x[\mathrm{MTau}] \cdot(1-x)[\mathrm{TfOH}]$ samples with a residual water content of $0.75-0.8 \mathrm{wt} \%$ and the second series were samples diluted with water to an $\mathrm{H}_{2} \mathrm{O}$ content of $6 \mathrm{wt} \%$, i.e., $x$ [MTau] $\cdot(1-x)[\mathrm{TfOH}]+6 \mathrm{wt} \% \mathrm{H}_{2} \mathrm{O}$. The (molar) ratio of $x$ [MTau] $\cdot(1-x)[\mathrm{TfOH}]: \mathrm{H}_{2} \mathrm{O}$ is in the range of $0.98-1.0$, due to the similar molar mass between $M_{\mathrm{Mtau}}=139$ and $M_{\mathrm{TfOH}}=150$. The different stoichiometries of the samples are illustrated in Fig. 1. The samples with the composition $x=0.3-0.5$ have a "TfOH-excess". Conversely, the samples with the composition $x=0.5-0.7$ (or 0.65) have an "MTau-excess".

\section{Conductivity measurement}

The AC conductivity measurements were performed in a fourprobe conductivity cell, using platinum electrodes. The cell constant as a function of the sample volume was determined by using a $0.1 \mathrm{M} \mathrm{KCl}$ solution for calibration. The intended water contents of the binary PIL $+\mathrm{H}_{2} \mathrm{O}$ mixtures were checked using Karl-Fischer titration at the beginning of each measurement. The total ohmic resistance $\sigma$ as a function of the temperature $T$ of the neat PIL and of the PIL $+\mathrm{H}_{2} \mathrm{O}$ samples was determined by means of impedance spectroscopy. The temperature $T$ was increased in increments of $10{ }^{\circ} \mathrm{C}$ from 60 to $110{ }^{\circ} \mathrm{C}$ and vice versa. The excitation amplitude was adjusted to $10 \mathrm{mV}$. The specific conductivity $\sigma$ was calculated by using the cell constant. 


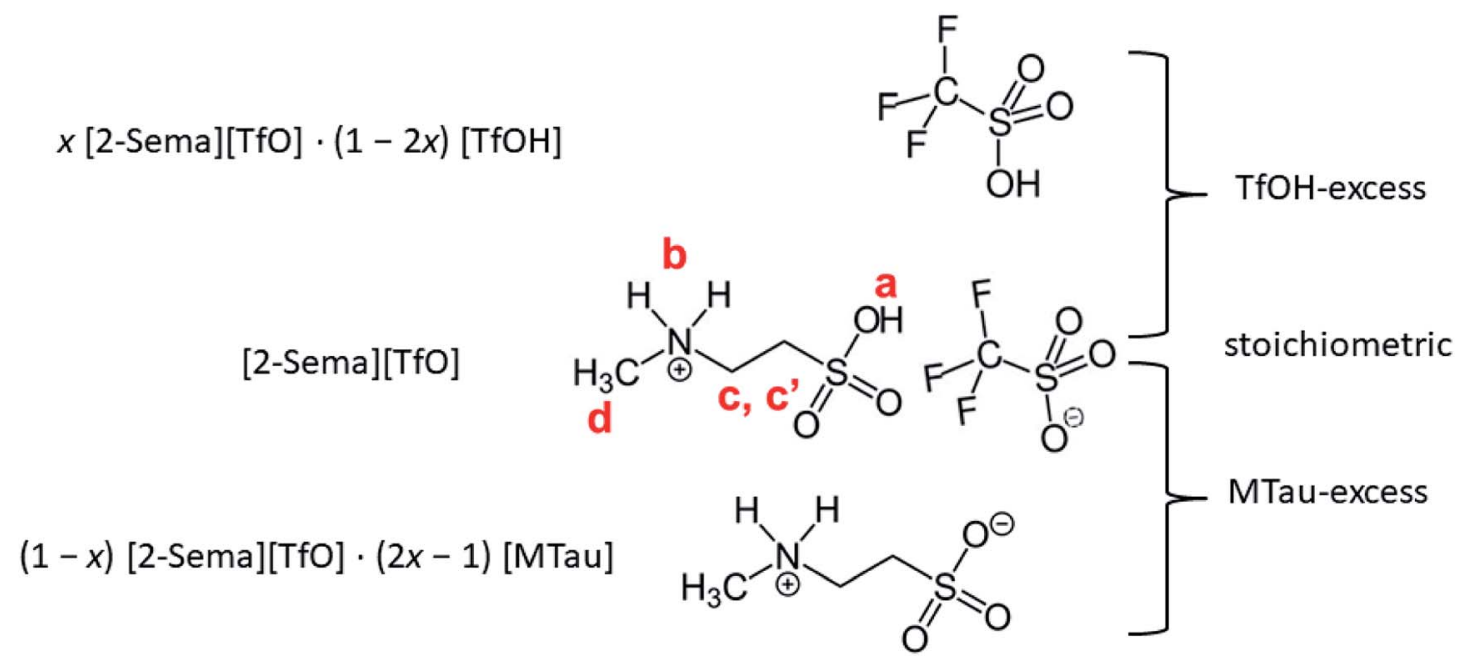

Fig. $1 x[\mathrm{MTau}] \cdot(1-x)[\mathrm{TfOH}]$ samples with an excess of the acid $\mathrm{TfOH}$ or the base $\mathrm{N}$-methyltaurine.

\section{${ }^{1}$ H NMR parameters}

The acquisition of the NMR spectra was performed using a Bruker $600 \mathrm{MHz}$ spectrometer, equipped with a $5 \mathrm{~mm}$ cryoprobe tuned to ${ }^{1} \mathrm{H}$. A capillary filled with $\mathrm{D}_{2} \mathrm{O}$ was enclosed the sample tubes as a field lock. The measurements were performed at $90{ }^{\circ} \mathrm{C}$, because at lower temperatures, the increasing viscosity leads to high relaxation times.

\section{Measurement of the self-diffusion coefficients}

The self-diffusion coefficients of the observable protons were measured using the diffusion-ordered spectroscopy (DOSY) technique at $90{ }^{\circ} \mathrm{C}$. The measurements were performed by applying 30 field gradient increments with a gradient strength $g$ from 1.3 to $32.5 \mathrm{G} \mathrm{cm}^{-1}$. The values of the gradient pulse length $\delta$ and the diffusion time intervals $\Delta$ were optimized to aim for least $85 \%$ signal attenuation at the strongest field gradient. The value of the (self-) diffusion coefficient $D_{\mathrm{i}}$ of a certain proton species i was obtained from the decay of its measured echo intensity $v s$. the gradient field strength $g$.

\section{Results and discussion}

\section{Total conductivity $v s$. stoichiometry and water content}

The measurements of the total conductivity $\sigma$ were performed in the temperature range between 60 and $110{ }^{\circ} \mathrm{C}$. The total conductivity includes cationic and anionic charge transport. In the $x[\mathrm{MTau}] \cdot(1-x)[\mathrm{TfOH}]$ and the $x[\mathrm{MTau}] \cdot+(1-x)[\mathrm{TfOH}]+$ $6 \mathrm{wt} \% \mathrm{H}_{2} \mathrm{O}$ samples, the viscosity was strongly dependent on the composition. In general, the viscosity was rising with an increasing fraction $x$ of the (at room temperature solid) base $N$ methyltaurine, i.e., with increasing MTau-excess. In the case of an increasing TfOH-excess, the viscosity was generally decreasing, i.e., with decreasing $x$. A higher content of $\mathrm{H}_{2} \mathrm{O}$ also leads to a lower viscosity. The dependence of the total conductivity $\sigma$, respectively of the specific total conductivity $\Lambda$ on the viscosity $\eta$, can be explained according to the StokesEinstein and Nernst-Planck relations:

$$
\Lambda \eta=\frac{e^{2} N_{\mathrm{A}}}{6 \pi} \sum_{\mathrm{i}} \frac{z_{\mathrm{i}}^{2} \nu_{\mathrm{i}}}{r_{\mathrm{i}}} \alpha_{\text {Diss }}=\text { const. with } \alpha_{\text {Diss }}=\frac{c_{\mathrm{i}}}{\nu_{\mathrm{i}} C_{0}} \text { and } \Lambda=\frac{\sigma}{C_{0}}
$$

Assuming an ionic compound $\mathrm{A}_{\nu_{1}} \mathrm{~B}_{\nu_{2}} \mathrm{C}_{\nu_{2}} \ldots \mathrm{X}_{\nu_{\mathrm{i}}}, \nu_{\mathrm{i}}$ denotes the stoichiometric factor, $z_{\mathrm{i}}$ the charge number and $r_{\mathrm{i}}$ the hydrodynamic radius of the ionic species $i$. In the case of a dissociation degree $\alpha_{\text {Diss }}$ not being equal to unity, the concentration of the ionic species $\mathrm{i}$ is denoted with $c_{\mathrm{i}}$ and the initial concentration of the ionic compound $\mathrm{A}_{\nu_{1}} \mathrm{~B}_{\nu_{2}} \mathrm{C}_{\nu_{2}} \ldots \mathrm{X}_{\nu_{1}}$ with $c_{0}$. Thus, a decrease in the viscosity will accelerate the vehicular proton transport by PIL cations and $\mathrm{H}_{3} \mathrm{O}^{+}$.

The dependency of the total conductivity $\sigma$ on the neat samples and samples with a water content of $6 \mathrm{wt} \%$ on the temperature $T$ and the stoichiometry $x$ is depicted in Fig. 2(a) and (b), respectively. The course of the conductivities corresponds to the change in the viscosity. In the case of the neat samples, depicted in Fig. 2(a), the sample with the smallest MTau molar fraction $x=0.3$ exhibits the highest total conductivity. Correspondingly, the total conductivities of the samples with a water content of $6 \mathrm{wt} \%$ are generally higher compared to the neat sample, as is depicted in Fig. 2(b).

For all of the investigated samples, the total conductivity $\sigma$ increases as a function of the temperature $T$. However, the extent of the conductivity increase $v s$. temperature is different. The highest impact on the conductivity was found for the sample with the highest MTau molar fraction of $x=0.7$. For this MTau molar fraction, in the case of the neat samples, $\sigma$ increases by a factor of 8.4 when $T$ rises from $60{ }^{\circ} \mathrm{C}$ to $110^{\circ} \mathrm{C}$. In the case of the sample with a molar fraction of $x=0.3$, the increase was only by a factor of 3 . The samples with a water content of $6 \mathrm{wt} \%$ and a molar fraction of $x=0.7$ and $x=0.3$ show a similar behaviour, with the conductivity increasing by a factor of 8.52 and 2.75 , respectively. The different factors may 


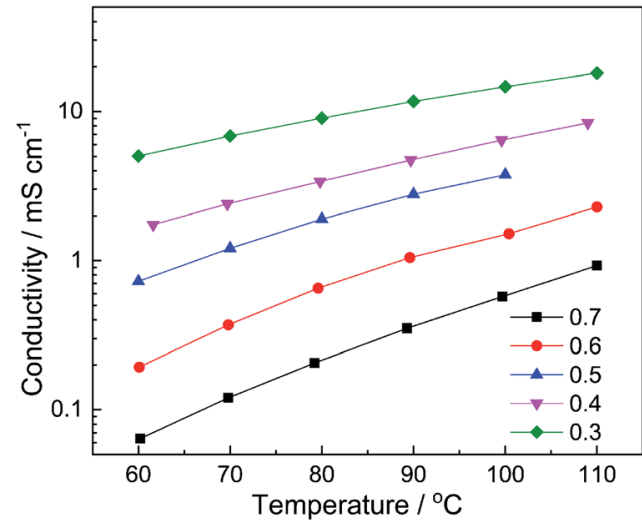

(a)

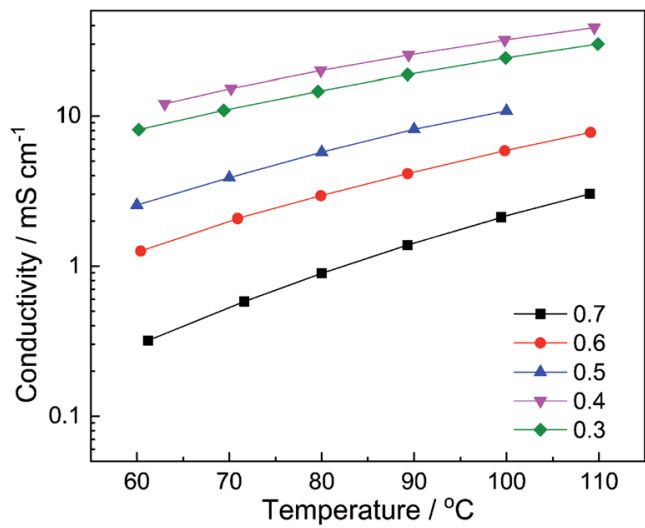

(b)

Fig. 2 The conductivity of: (a) neat $x[\mathrm{MTau}] \cdot(1-x)[\mathrm{TfOH}](0.75-0.8 \mathrm{wt} \%)$; and (b) $x[\mathrm{MTau}] \cdot(1-x)[\mathrm{TfOH}]+6$ wt $\% \mathrm{H}_{2} \mathrm{O}$ samples as a function of the temperature. The molar fraction of $N$-methyltaurine varies from $x=0.3$ to 0.7 .

indicate that there is not only a change in viscosity but also of the proton transport mechanism responsible for the increase in the total conductivity when increasing the molar fraction of MTau. The total conductivity describes the bulk charge transport macroscopically and includes all mobile charge carriers ([2Sema $]^{+}$, [TfO $]^{-}$and $\mathrm{H}_{3} \mathrm{O}^{+}$). The underlying ionic charge (proton) transport mechanisms can only be discerned by techniques sensitive to the local environment of the mobile charge carriers, i.e., the NMR.

\section{${ }^{1}$ H-NMR of neat $x[$ MTau $] \cdot(1-x)[$ TfOH $]$ samples}

In the following, ${ }^{1} \mathrm{H}$-NMR and ${ }^{1} \mathrm{H}$-PFG-NMR are used to measure the local dynamics of the mobile protonic charge carriers, as well as their self-diffusion coefficients. As discussed above, in a PIL of the type $\mathrm{HB}^{+} \mathrm{A}^{-}$, an excess of the base $\mathrm{B}$ as well as a certain water content are able to provide cooperative transport and thus improve the proton conductivity. Therefore, depending on the excess of the base and water content, both transport mechanisms, vehicular and cooperative, may be present in a sample.

Due to the high viscosity of the samples at room temperature, especially in the case of MTau-excess, the NMR measurements were all performed at $90{ }^{\circ} \mathrm{C}$ to avoid an FWHM of the signals too broad to evaluate. The ${ }^{1} \mathrm{H}$ NMR spectra of $x$ $[\mathrm{MTau}] \cdot(1-x)[\mathrm{TfOH}](x=0.3-0.7)$ at a temperature of $90{ }^{\circ} \mathrm{C}$ are depicted in Fig. 3(a) and the chemical shift $\delta$ of the protons situated in the $\mathrm{SO}_{3} \mathrm{H}$ and $\mathrm{NH}_{2}{ }^{+}$group $v s$. the stoichiometry $x$ in Fig. 3(b). The signals of the protons are labelled with (a), (b), (c, $\left.\mathrm{c}^{\prime}\right)$ and (d), according to Fig. 1. In the case of the stoichiometric [2-Sema][TfO] sample, i.e., $x=0.5$, the protons of the $\mathrm{NH}_{2}{ }^{+}$ group (b) show up at a chemical shift $\delta$ of $6.83 \mathrm{ppm}$ and the proton of the $\mathrm{SO}_{3} \mathrm{H}$ group (a) at $12.25 \mathrm{ppm}$. When increasing the mole fraction $x$ of the base MTau from 0.3 to 0.7 , the signal (b) of the $\mathrm{NH}_{2}{ }^{+}$protons shifts about $0.6 \mathrm{ppm}$ towards the lower magnetic field, i.e., from a chemical shift of 6.49 to $7.10 \mathrm{ppm}$. In the case of $\mathrm{SO}_{3} \mathrm{H}$ protons (a) there is a slight shift of $+0.06 \mathrm{ppm}$ towards lower magnetic fields when increasing $x$ from 0.3 to 0.4 and a slight shift of -0.17 ppm towards higher magnetic fields from 0.4 to 0.5 . Beyond the stoichiometric composition, for a molar fraction $x$ of 0.5 to 0.7 , the signal shifts about $+0.9 \mathrm{ppm}$ towards lower magnetic fields with increasing the base excess. The signal of the protons of the $\mathrm{CH}_{3}$ group (d) show up at a chemical shift $\delta$ of $2.63 \mathrm{ppm}$ and of the $\mathrm{CH}_{2} \mathrm{CH}_{2}$ backbone (c, $c^{\prime}$ ) at about $3.37 \mathrm{ppm}$. There is no appreciable shift in the $\mathrm{CH}_{3}$

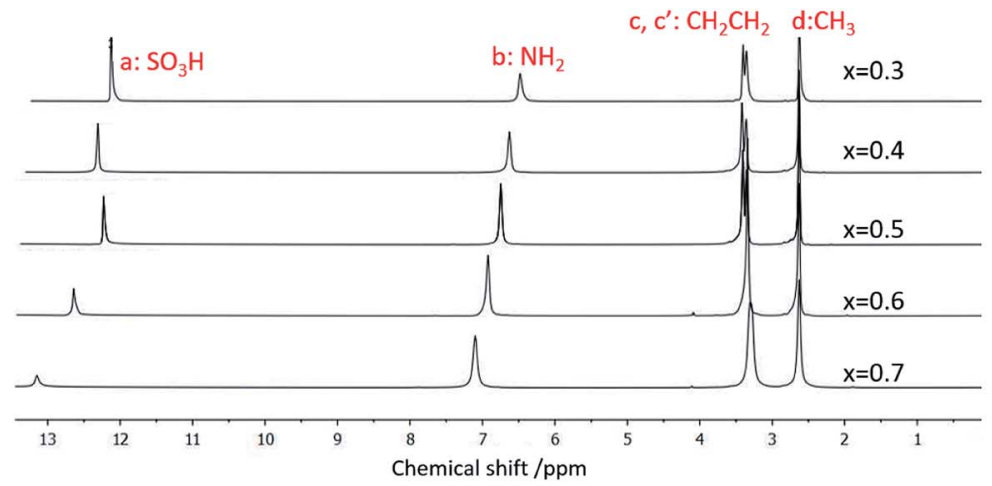

(a)

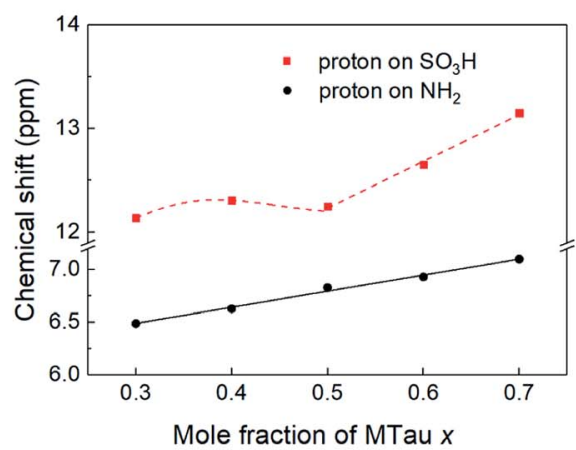

(b)

Fig. 3 (a) The ${ }^{1} \mathrm{H}$ NMR spectra and (b) the ${ }^{1} \mathrm{H}$ NMR spectra chemical shift (ppm) of $\mathrm{SO}_{3} \mathrm{H}$ and $\mathrm{NH}_{2}$ of neat $x[\mathrm{MTau}] \cdot(1-x)[\mathrm{TfOH}]$ at $90{ }^{\circ} \mathrm{C}$. 
(d) and the $\mathrm{CH}_{2} \mathrm{CH}_{2}\left(\mathrm{c}, \mathrm{c}^{\prime}\right)$ protons. In the case of samples with a base-excess, i.e., $x>0.5$, the protons of the $\mathrm{CH}_{2} \mathrm{CH}_{2}$ backbone $\left(\mathrm{c}, \mathrm{c}^{\prime}\right)$ are difficult to distinguish due to a general increase of the FWHM in the spectra.

The NMR chemical shift $\delta$ of a proton depends on the local screening of the external magnetic field by the local electron density. In the timescale of the NMR experiment, a chemical shift to a lower field represents a generally lower local electron density or higher "delocalization" of the proton. The local electron density can be affected by intramolecular interactions with adjacent groups or intermolecular interactions by hydrogen bonds. A high acidic proton is accompanied by a low local electron density. In addition, the formation of a hydrogen bond leads to the deshielding of a proton. Thus, the (NMR-) active protons of a Brønsted-acidic PIL in particular are influenced not only by the water content but also by the acid-base stoichiometry, as the active protons can easily form hydrogen bonds and are subject to intramolecular interactions. In the case of the water-free samples, the molar fractions of the species $[2-\mathrm{Sema}]^{+}$, MTau, TfOH and $[\mathrm{TfO}]^{-}$should vary as a function of the stoichiometry $x$, as depicted in Fig. 4. $\mathrm{TfOH}$ is a much stronger acid compared to the $[2-\mathrm{Sema}]^{+}$cation, and so we can safely assume a complete proton transfer from TfOH to MTau for the entire range of stoichiometry $x$. This should lead to a decreasing fraction of $\mathrm{TfOH}$ in the stoichiometric range from $x=0$ to $1 / 2$ and an increasing fraction of MTau in the range from $x=1 / 2$ to 1 .

As the acidity of the $\mathrm{NH}_{2}{ }^{+}$moiety in the $[2 \text {-Sema }]^{+}$cation and MTau is not sufficient to protonate $\mathrm{SO}_{3}{ }^{-}$moieties (intra/ intermolecular) to a noticeable extent, the residence time prior to re-transfer should be very short. Thus, protolysis equilibria should not contribute to the observed stoichiometry $x$ dependent shift of these protons $\left(\mathrm{p} K_{\mathrm{A} 2}\right.$ of $\mathrm{NH}_{2}{ }^{+}$in MTau, about 10.2). ${ }^{27-29}$ As is shown in Fig. 4, the sum of the molar fractions of $[\mathrm{MTau}]$ and $[\mathrm{TfO}]^{-}$is increasing when increasing $x$ from 0.3 to 0.7. Thus, in the case of the $\mathrm{NH}_{2}{ }^{+}$protons, only the probability of forming $\mathrm{H}$-bonds with neighboring $[\mathrm{TfO}]^{-}$anions and [2Sema $]^{+}$cations and excess MTau molecules, respectively, can be

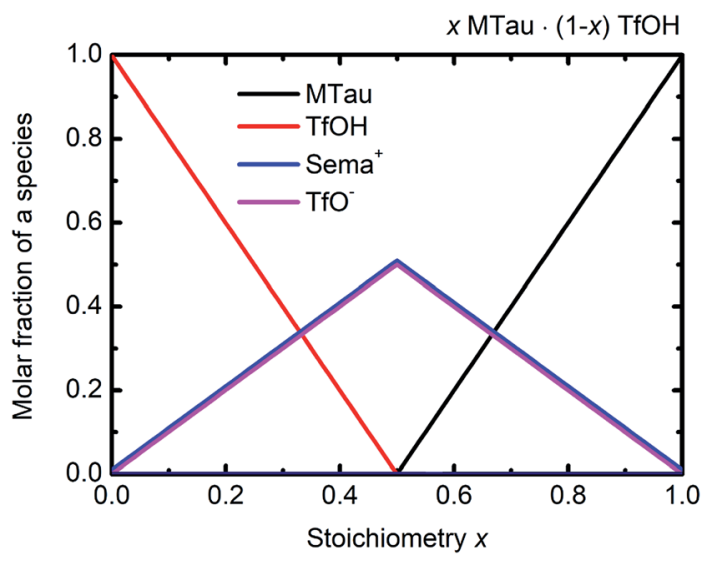

Fig. 4 Molar fractions of the species [2-Sema] ${ }^{+}, \mathrm{MTau}, \mathrm{TfOH}$ and $[\mathrm{TfO}]^{-}$as a function of the stoichiometry $x$ for the samples $x \mathrm{MTau} \cdot(1-$ $x) \mathrm{TfOH}$. The curves of $[2-\mathrm{Sema}]^{+}$and $[\mathrm{TfO}]^{-}$coincide. considered to explain the observation that the $\delta$ value of the $\mathrm{NH}_{2}{ }^{+}$protons shifts monotonically towards lower fields with a slope of $0.15 \mathrm{ppm} / 0.1 \Delta x$ (deshielding).

In the case of $\mathrm{SO}_{3} \mathrm{H}$ protons, a stronger effect can be observed compared to the $\mathrm{NH}_{2}{ }^{+}$protons. Despite the fact that $\mathrm{SO}_{3} \mathrm{H}$ protons are present on $[2-\mathrm{Sema}]^{+}$cations and $\mathrm{TfOH}$, there is only one signal shifting from 12.14 to $13.15 \mathrm{ppm}$ to lower fields. The sites cannot be distinguished on the NMR spectrum. In addition to the possibility of forming $\mathrm{H}$-bonds, the possibility/frequency of intermolecular proton transfers must also be considered. In the case of MTau-excess, i.e., for samples with a stoichiometry of $x=0.5$ to 0.7 , there will be only variable fractions of $[2-\mathrm{Sema}]^{+}$, MTau and $[\mathrm{TfO}]^{-}$. The acidity of $\mathrm{TfOH}$ $\left(\mathrm{p} K_{\mathrm{A}}=-14\right)$ is much higher than that of $[2-\mathrm{Sema}]^{+}\left(\mathrm{p} K_{\mathrm{A}}=-1\right) .{ }^{27}$ The proton transfer from the cation $[2-\mathrm{Sema}]^{+}$back to the [TfO] ${ }^{-}$ anion will not take place to a noticeable degree. Thus, $\mathrm{TfOH}$ is fully deprotonated. There are only fast intermolecular proton transfers between $\mathrm{SO}_{3}{ }^{-}$moieties of $[2-\mathrm{Sema}]^{+}$and MTau, resulting in the strong deshielding of the proton with increasing $x$ :

$$
\begin{aligned}
& \mathrm{CH}_{3} \mathrm{NH}_{2}^{+}\left(\mathrm{CH}_{2}\right)_{2} \mathrm{SO}_{3} \mathrm{H}+\mathrm{CH}_{3} \mathrm{NH}_{2}^{+}\left(\mathrm{CH}_{2}\right)_{2} \mathrm{SO}_{3}{ }^{-} \rightarrow \\
& \mathrm{CH}_{3} \mathrm{NH}_{2}^{+}\left(\mathrm{CH}_{2}\right)_{2} \mathrm{SO}_{3}^{-}+\mathrm{CH}_{3} \mathrm{NH}_{2}^{+}\left(\mathrm{CH}_{2}\right)_{2} \mathrm{SO}_{3} \mathrm{H}(4)
\end{aligned}
$$

In the stoichiometry range between $x=0.5$ to 0.7 , the signal shifts with a slope of $0.45 \mathrm{ppm} / 0.1 \Delta x$; see Fig. 4 .

In the case of $\mathrm{TfOH}$-excess, i.e., for samples with a stoichiometry of $x=0.3$ to 0.5 , the shift in the signal is comparably small and not monotonic. Due to the $\mathrm{TfOH}$ excess, the $\mathrm{SO}_{3} \mathrm{H}$ moiety of the MTau is fully protonated. There are only variable fractions of $[2 \text {-Sema }]^{+}$cations, $\mathrm{TfOH}$ and $[\mathrm{TfO}]^{-}$. Thus, there is primarily an intermolecular proton transfer between the anion $[\mathrm{TfO}]^{-}$and $\mathrm{TfOH}$, which also results in a de-shielding of the proton:

$$
\mathrm{CF}_{3} \mathrm{SO}_{3} \mathrm{H}+\mathrm{CF}_{3} \mathrm{SO}_{3}{ }^{-} \rightarrow \mathrm{CF}_{3} \mathrm{SO}_{3}{ }^{-}+\mathrm{CF}_{3} \mathrm{SO}_{3} \mathrm{H}
$$

Changing the stoichiometry from $x=0.5$ to 0.4 leads to an increasing delocalization of the $\mathrm{SO}_{3} \mathrm{H}$ proton and to an initial downfield shift, as seen in the NMR chemical shift in Fig. 3(b). In the system $\mathrm{TfOH} /[\mathrm{TfO}]^{-}$, the presence of $[\mathrm{TfO}]^{-}$should be equivalent to the excess base MTau in the system [2-Sema $]^{+} / \mathrm{MTau}$. Thus, a further increase in the molar fraction of $\mathrm{TfOH}$ may inhibit the delocalization again, resulting in the observed shift of the $\mathrm{SO}_{3} \mathrm{H}$ proton back towards the higher field when changing the stoichiometry from $x=0.4$ to 0.3 , due to the restricted mobility.

In the case of the neat, nearly water-free samples, a change in the stoichiometry will affect the probability and duration of forming hydrogen bonds to the $\mathrm{NH}_{2}$ proton on cations in the timescale of the NMR measurement. In the case of the $\mathrm{SO}_{3} \mathrm{H}$ proton, the MTau-excess leads to a significant delocalization between the $\mathrm{SO}_{3}{ }^{-} / \mathrm{SO}_{3} \mathrm{H}$ sites in the timescale of the NMR measurement and $\mathrm{TfOH}$-excess results to a delocalization between the $[\mathrm{TfO}]^{-} / \mathrm{TfOH}$. Both of these may explain the observed signal shift to high magnetic fields in the ${ }^{1} \mathrm{H}$ NMR spectrum. The acid-base stoichiometry also influences the proton transport processes. The observation of a proton delocalisation on the NMR timescale indicates the possible presence 


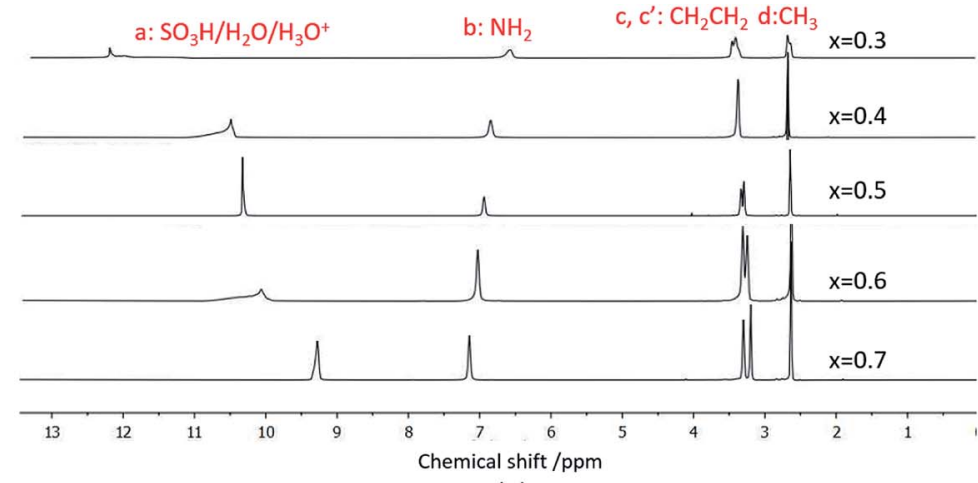

(a)

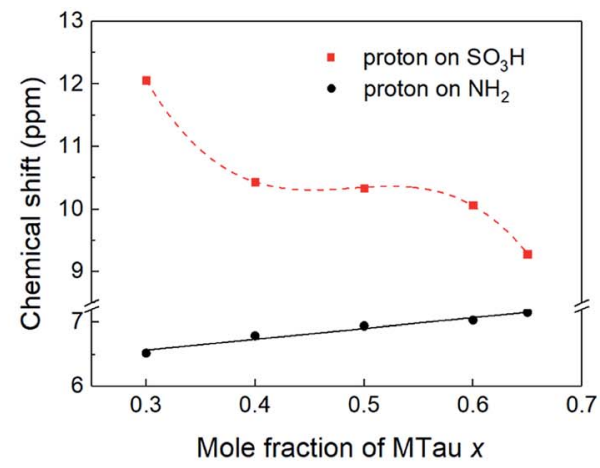

(b)

Fig. 5 (a) The ${ }^{1} \mathrm{H}$ NMR spectra; (b) the ${ }^{1} \mathrm{H}$ NMR spectra chemical shift (ppm) of $\mathrm{SO}_{3} \mathrm{H}$ and $\mathrm{NH}_{2}$ of 6 wt\% water concentration $x[M T a u] \cdot(1-x)$ $[\mathrm{TfOH}]+6 \mathrm{wt} \% \mathrm{H}_{2} \mathrm{O}$ at $90^{\circ} \mathrm{C}$.

of intermolecular (cooperative) proton transport. The influence of the proton delocalization on the proton transport will be discussed in relation to the self-diffusion coefficient in the section "H-PFG-NMR".

\section{${ }^{1} \mathrm{H}$-NMR of $x[$ MTau] $\cdot(1-x)[$ TfOH] samples with $6 \mathrm{wt} \%$ water}

The ${ }^{1} \mathrm{H}$ NMR spectra of $x[\mathrm{MTau}] \cdot(1-x)[\mathrm{TfOH}](x=0.3-0.65)$ with a water content of $6 \mathrm{wt} \%$ at $90{ }^{\circ} \mathrm{C}$ is depicted in Fig. 5(a) and the chemical shift $\delta v s$. stoichiometry $x$ of the of $\mathrm{SO}_{3} \mathrm{H}$ and $\mathrm{NH}_{2}{ }^{+}$protons in Fig. 5(b). Similar to the ${ }^{1} \mathrm{H}$ NMR spectrum of (neat) $x[\mathrm{MTau}] \cdot(1-x)[\mathrm{TfOH}]$ samples, the protons of the $\mathrm{CH}_{3}$ group in $x[\mathrm{MTau}] \cdot(1-x)[\mathrm{TfOH}]+6 \mathrm{wt} \% \mathrm{H}_{2} \mathrm{O}$ can be found at $2.63 \mathrm{ppm}$. The protons of the $\mathrm{CH}_{2} \mathrm{CH}_{2}$ backbone (c, $\left.\mathrm{c}^{\prime}\right)$ appear as two separated signals in most of the samples. These can be found at about 3.30 and $3.25 \mathrm{ppm}$. When increasing the MTau mole fraction, the signal of the $\mathrm{NH}_{2}^{+}$protons also shifts towards a lower magnetic field, as is observed for the neat samples. It shifts from 6.52 to $7.15 \mathrm{ppm}$ (about $+0.6 \mathrm{ppm}$ ) when changing $x$ from 0.3 to 0.65 . A higher water concentration will generally increase the number of species available to form $\mathrm{H}$-bonds (leading to a deshielding), which may provide an additional shift of $\sim+0.05 \mathrm{ppm}$ for all stoichiometric compositions compared to the (neat) $x[\mathrm{MTau}] \cdot(1-x)[\mathrm{TfOH}]$ samples. The slope of $0.18 \mathrm{ppm} / 0.1 \Delta x$ is slightly higher.

In the investigated stoichiometry range from $x=0.3$ to 0.65 , the signal of the $\mathrm{SO}_{3} \mathrm{H}$ proton shifts in the opposite direction compared to the (neat) $x[\mathrm{MTau}] \cdot(1-x)[\mathrm{TfOH}]$ samples, i.e., towards higher fields (from 12.1 to $9.3 \mathrm{ppm}$ ). The additional $\mathrm{H}_{2} \mathrm{O}$ in $x[\mathrm{MTau}] \cdot(1-x)[\mathrm{TfOH}]+6 \mathrm{wt} \% \mathrm{H}_{2} \mathrm{O}$ samples acts as another proton acceptor. Depending on the stoichiometric composition $x$, it can be protonated by the very high acidic excess TfOH or by the high acidic [2-Sema $]^{+}$cation according to the protolysis equilibria shown in eqn (6) and (7):

$$
\begin{aligned}
& \mathrm{CH}_{3} \mathrm{NH}_{2}{ }^{+}\left(\mathrm{CH}_{2}\right)_{2} \mathrm{SO}_{3} \mathrm{H}+\mathrm{H}_{2} \mathrm{O} \\
& \underset{k_{2}}{\stackrel{k_{1}}{\rightleftarrows}} \mathrm{CH}_{3} \mathrm{NH}_{2}{ }^{+}\left(\mathrm{CH}_{2}\right)_{2} \mathrm{SO}_{3}^{-}+\mathrm{H}_{3} \mathrm{O}^{+} \\
& \mathrm{TfOH}+\mathrm{H}_{2} \mathrm{O} \rightarrow \mathrm{TfO}^{-}+\mathrm{H}_{3} \mathrm{O}^{+}
\end{aligned}
$$

TfOH is the much stronger acid compared to the [2-Sema $]^{+}$ cation and the acidity of the hydroxonium cation $\mathrm{H}_{3} \mathrm{O}^{+}$is on the same order as the acidity of the $[2-\mathrm{Sema}]^{+}$cation. $\dot{\dagger}^{30,31} \mathrm{~A}$ preceding work confirms the fast exchange of the $\mathrm{H}_{2} \mathrm{O}$ proton and $\mathrm{SO}_{3} \mathrm{H}$ proton, resulting in a single signal in the spectrum of $\mathrm{SO}_{3} \mathrm{H} / \mathrm{H}_{3} \mathrm{O}^{+} / \mathrm{H}_{2} \mathrm{O}$ at an average NMR shift. ${ }^{25}$ Moreover, the signal of the $\mathrm{SO}_{3} \mathrm{H}$ proton shows a corresponding increase in its integral area with increasing $\mathrm{H}_{2} \mathrm{O}$ content, which is not the case for the $\mathrm{NH}_{2}{ }^{+}$or alkyl protons.

Considering the protolysis reactions in eqn (6) and (7), below a stoichiometry $x$ of 0.24 , all existing MTau and $\mathrm{H}_{2} \mathrm{O}$ will be protonated by the excess $\mathrm{TfOH}$ in the $x[\mathrm{MTau}] \cdot(1-x)[\mathrm{TfOH}]+$ $6 \mathrm{wt} \% \mathrm{H}_{2} \mathrm{O}$ samples. $\$$ Part of the excess TfOH should be undissociated. There will only be $[2-\mathrm{Sema}]^{+}, \mathrm{H}_{3} \mathrm{O}^{+}$, TfOH and $[\mathrm{TfO}]^{-}$in the samples. At a stoichiometry $x$ above 0.24 , unprotonated MTau and $\mathrm{H}_{2} \mathrm{O}$ should be present, as all TfOH is dissociated, i.e., only [ $[\mathrm{ffO}]^{-}$should exist in this range. With an increasing fraction of $\mathrm{H}_{2} \mathrm{O}$, a portion of the [2-Sema $]^{+}$cations can also be deprotonated. Taking the preceding investigations of the analog compound 2-sulfoethylammonium triflate into account, a protolysis degree of the $[2-\mathrm{Sema}]^{+}$cation of about 0.3 can be estimated for a sample with a stoichiometric composition $(x=0.5){ }^{32}$ These assumptions are underpin the construction of the tentative plot in Fig. 6.

In the case of the investigated $x[\mathrm{MTau}] \cdot(1-x)[\mathrm{TfOH}]+$ $6 \mathrm{wt} \% \mathrm{H}_{2} \mathrm{O}$ samples with a stoichiometry of $x=0.3$ to 0.65 , the very high acidic TfOH should always be fully consumed by protonating the $\mathrm{H}_{2} \mathrm{O}$ molecules and forming $\mathrm{H}_{3} \mathrm{O}^{+}$cations, respectively, by protonating $\mathrm{MTau}$, forming $[2 \text {-Sema }]^{+}$cations; see Fig. 6. Thus, there will only be $[2-\mathrm{Sema}]^{+}, \mathrm{MTau}, \mathrm{H}_{3} \mathrm{O}^{+}, \mathrm{H}_{2} \mathrm{O}$ and $[\mathrm{TfO}]^{-}$. Here, the intermolecular transfer between $\mathrm{TfOH}$ and [TfO $]^{-}$, as stated in eqn (5), would not take place. As MTau will act as a proton acceptor, the equilibrium fractions of $\mathrm{H}_{2} \mathrm{O}$, $\mathrm{H}_{3} \mathrm{O}^{+}$and $\left[\mathrm{Sema}^{+}\right]$cations depend on the stoichiometry $x$ according eqn (6) and (7). Increasing the stoichiometry $x$ from

\footnotetext{
$\dagger$ The $\mathrm{p} K_{\mathrm{A}}$ of $\mathrm{H}_{3} \mathrm{O}^{+}$is equal to 0 , the $\mathrm{p} K_{\mathrm{A}}$ of typical alkane sulfonic acids is about -1 .

$\$$ This corresponds to an initial molar fraction of 0.50 for TfOH, 0.16 for MTau and 0.34 for $\mathrm{H}_{2} \mathrm{O}$, considering the molar weights and a water content of $6 \mathrm{wt} \%$.
} 


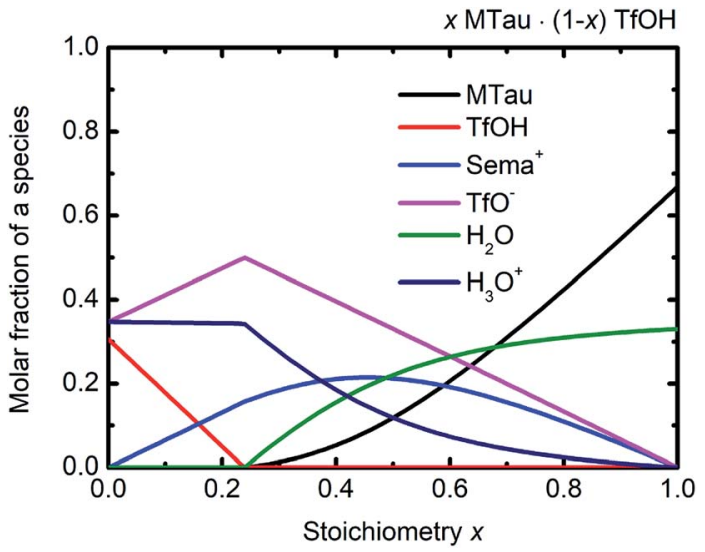

Fig. 6 (Tentative) molar fractions of the species [2-Sema $]^{+}, \mathrm{MTau}$, $\mathrm{TfOH},[\mathrm{TfO}]^{-}, \mathrm{H}_{3} \mathrm{O}^{+}$and $\mathrm{H}_{2} \mathrm{O}$ as a function of the stoichiometry $x$ for the samples $x$ MTau $\cdot(1-x) \mathrm{TfOH}+\mathrm{H}_{2} \mathrm{O}$.

0.3 to 0.65 should lead to a decreasing fraction of $\mathrm{H}_{3} \mathrm{O}^{+}$and an increasing fraction of $\mathrm{H}_{2} \mathrm{O}$. The fraction of the [2-Sema] $]^{+}$cations will reach a maximum in close proximity to the stoichiometric point $x=1 / 2$. There is a delocalization of the active proton in the NMR timescale between $\mathrm{H}_{2} \mathrm{O}, \mathrm{H}_{3} \mathrm{O}^{+}$, MTau and [2-Sema] $]^{+}$, because the neutral MTau is competing with $\mathrm{H}_{2} \mathrm{O}$ for the protons of the [2-Sema] $]^{+}$and $\mathrm{H}_{3} \mathrm{O}^{+}$cations. The chemical shift found for the $\mathrm{H}_{3} \mathrm{O}^{+}$protons $(\sim 9.6-10.9 \mathrm{ppm})$ is at a much lower magnetic field compared to $\mathrm{H}_{2} \mathrm{O}(\sim 3-5 \mathrm{ppm}){ }^{33}$ Thus, the averaged ppm value of the $\mathrm{SO}_{3} \mathrm{H} / \mathrm{H}_{3} \mathrm{O}^{+} / \mathrm{H}_{2} \mathrm{O}$ proton should also decrease, respectively shifting towards a higher field, as it inclines to the ppm value of $\mathrm{H}_{2} \mathrm{O}$; see Fig. 5 .

The proton transport mechanism is further discussed, together with the ${ }^{1} \mathrm{H}$-PFG-NMR/DOSY measurements and the self-diffusion coefficient in the next section. The mobile protonic charge carriers in the $\mathrm{PIL} / \mathrm{H}_{2} \mathrm{O}$ system are [2-Sema $]^{+}$ and, due to protolysis, also the $\mathrm{H}_{3} \mathrm{O}^{+}$cations. In the case of vehicular transport, the $\mathrm{H}_{3} \mathrm{O}^{+}$cations are probably much more mobile than the [2-Sema $]^{+}$ones. For a stoichiometry $x>0.3$, the fractions of $\mathrm{H}_{3} \mathrm{O}^{+}$and $[\mathrm{TfO}]^{-}$monotonously decrease with increasing $x$. The fraction of $[2-\mathrm{Sema}]^{+}$reaches a maximum at $x$ $\approx \frac{1}{2}$. If there is only vehicular transport, this should principally lead to a decrease in the (total) conductivity with increasing $x$. If there is also cooperative transport, the presence of $\mathrm{H}_{2} \mathrm{O}$, acting as a proton acceptor, will also accelerate the intermolecular proton transfer between the MTau and the $[2 \text {-Sema }]^{+}$cation, leading to faster cooperative transport. For a stoichiometry of $x$ $>0.3$, the fraction of (free) $\mathrm{H}_{2} \mathrm{O}$ increases with increasing $x$. A maximum of an additional cooperative transport and thus of the (total) conductivity should be expected when the equimolar fractions of $\mathrm{H}_{2} \mathrm{O}$ and $\mathrm{H}_{3} \mathrm{O}^{+}$are present (the maximum probability for proton transfers between $\mathrm{H}_{3} \mathrm{O}^{+}$and $\mathrm{H}_{2} \mathrm{O}$ ). This is approximately the case for a stoichiometry $x \approx 0.4$ and corresponds well to the measured values for the total conductivity which exhibits a maximum at this stoichiometry; see Fig. 2(b) and 6. However, the total conductivity is highly coupled with the viscosity. At a higher stoichiometric composition $x>0.4$, the vehicular transport is again attenuated and thus the conductivity is decreased.

\section{${ }^{1}$ H-PFG-NMR/DOSY}

The self-diffusion coefficient of the protons is measured by ${ }^{1} \mathrm{H}$ PFG-NMR at $90^{\circ} \mathrm{C}$. The diffusion coefficient $D_{\mathrm{H}^{+}}$of the (active) $\mathrm{SO}_{3} \mathrm{H} / \mathrm{H}_{2} \mathrm{O} / \mathrm{H}_{3} \mathrm{O}^{+}$proton and $D_{\text {cation }}$ of the other protons of the [2-Sema $^{+}$cation/MTau are depicted in Table 1 for neat $x$ $[\mathrm{MTau}] \cdot(1-x)[\mathrm{TfOH}]$ and for $x[\mathrm{MTau}] \cdot(1-x)[\mathrm{TfOH}]+\mathrm{H}_{2} \mathrm{O}$, i.e. with a water content of $6 \mathrm{wt} \%$. The value of the diffusion coefficient for the $\mathrm{NH}_{2}$ protons is nearly the same as for the $\mathrm{CH}_{2} \mathrm{CH}_{2}$ and $\mathrm{CH}_{3}$ protons. Thus, these can be identified as the diffusion coefficient $D_{\text {cation }}$ of the entire cation, respectively, to the diffusion coefficient $D_{\mathrm{H}^{+} \text {,vehicle }}$ of protons only by means of a vehicular mechanism. The diffusion coefficient $D_{\mathrm{H}^{+}}$of the $\mathrm{SO}_{3} \mathrm{H} / \mathrm{H}_{2} \mathrm{O} / \mathrm{H}_{3} \mathrm{O}^{+}$protons is significantly higher compared to the diffusion coefficient $D_{\text {cation }}$ of the [2-Sema] $]^{+}$cation in all of the samples. As discussed, the observed intermolecular protons transfer between the $\mathrm{SO}_{3} \mathrm{H}$ moieties, $\mathrm{H}_{2} \mathrm{O}$ and $\mathrm{H}_{3} \mathrm{O}^{+}$, indicating the presence of cooperative transport and resulting in higher values of $D_{\mathrm{H}^{+}}$compared to $D_{\text {cation }}$.

As observed for the total conductivity $\sigma$, the diffusion coefficient $D_{\mathrm{H}^{+}}$of the active proton and $D_{\text {cation }}$ of the [2-Sema $]^{+}$ cation are decreasing with increasing stoichiometry $x$ (from 0.3 to 0.65 , respectively, to 0.7 ). The dynamic viscosity $\eta$ of the samples is directly coupled to the diffusion coefficient of the [2Sema $]^{+}$cation $D_{\text {cation }}$ due to the Stokes-Einstein relation. In the case of cooperative transport, there is a distinct decoupling from viscous processes. Thus, if vehicular and cooperative mechanisms are both present, an increase in viscosity will increase the impact of cooperative transport to the total proton transport. The share of cooperative processes in all of the samples is evaluated by calculating the ratio between $D_{\mathrm{H}^{+} \text {,coop }}$ to $D_{\mathrm{H}^{+}}$as follows: ${ }^{25}$

$$
\frac{D_{\mathrm{H}^{+}, \text {coop }}}{D_{\mathrm{H}^{+}}}=\frac{D_{\mathrm{H}^{+}}-D_{\mathrm{H}^{+}, \text {vehicle }}}{D_{\mathrm{H}^{+}}}
$$

The diffusion coefficient $D_{\mathrm{H}^{+} \text {,vehicle }}$ for vehicular transport is identical to that of the $[2-\mathrm{Sema}]^{+}$cation. The ratio represents the share of cooperative transport in the total proton diffusion process. The share of cooperative transport is depicted in Fig. 7. With increasing stoichiometry $x$, i.e., with an increasing fraction of MTau, the share of cooperative transport is also increasing

Table 1 Self-diffusion coefficients of the $\mathrm{SO}_{3} \mathrm{H} / \mathrm{H}_{2} \mathrm{O} / \mathrm{H}_{3} \mathrm{O}^{+}\left(\equiv D_{\mathrm{H}^{+}}\right)$ and the cation protons in neat $x[\mathrm{MTau}] \cdot(1-x)[\mathrm{TfOH}]$ and 6 wt $\%$ water concentration $x[\mathrm{MTau}] \cdot(1-x)[\mathrm{TfOH}]+\mathrm{H}_{2} \mathrm{O}$ at $90{ }^{\circ} \mathrm{C}$

\begin{tabular}{llllll}
\hline & \multicolumn{2}{l}{$\begin{array}{l}D_{\mathrm{i}} / 10^{-6} \mathrm{~cm}^{2} \mathrm{~s}^{-1} \text { in neat } \\
\text { samples }\end{array}$} & & \multicolumn{2}{l}{$\begin{array}{l}D_{\mathrm{i}} / 10^{-6} \mathrm{~cm}^{2} \mathrm{~s}^{-1} \text { in } \\
\text { Samples with } 6 \mathrm{wt} \% \mathrm{H}_{2} \mathrm{O}\end{array}$} \\
\cline { 2 - 3 } $\begin{array}{llllll}\text { MTau molar } \\
\text { fraction } x\end{array}$ & $\mathrm{H}^{+}$ & Cation & & $\mathrm{H}^{+}$ & Cation \\
\hline 0.3 & $15.4 \pm 0.7$ & $11.7 \pm 0.7$ & & $12.2 \pm 1.3$ & $7.20 \pm 0.9$ \\
0.4 & $4.63 \pm 0.4$ & $3.00 \pm 0.3$ & & $9.35 \pm 1.3$ & $3.15 \pm 0.6$ \\
0.5 & $1.31 \pm 0.0$ & $0.66 \pm 0.0$ & $6.00 \pm 0.1$ & $1.65 \pm 0.1$ \\
0.6 & $1.13 \pm 0.2$ & $0.56 \pm 0.2$ & & $4.95 \pm 0.4$ & $1.05 \pm 0.3$ \\
0.65 & - & - & $8.14 \pm 0.4$ & $1.51 \pm 0.4$ \\
0.7 & $0.75 \pm 0.1$ & $0.34 \pm 0.2$ & - & -
\end{tabular}




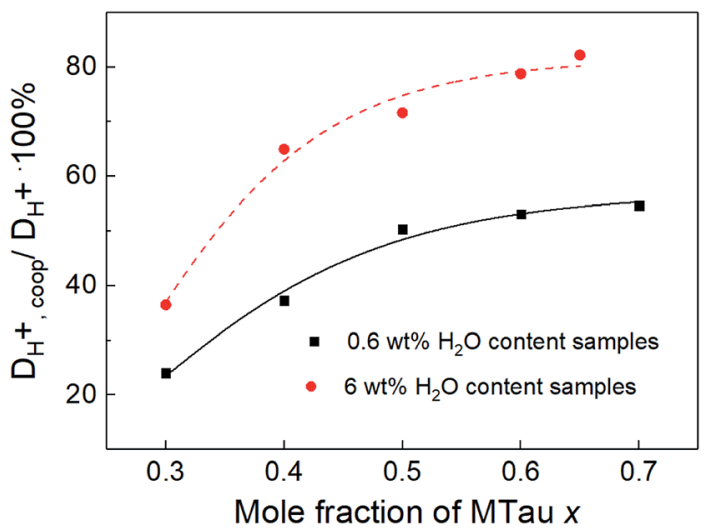

Fig. 7 The ratio of $D_{\mathrm{H}^{+} \text {,coop }}$ to $D_{\mathrm{H}^{+}}$in all of the measured samples.

for the neat samples and for samples with a water content of $6 \mathrm{wt} \%$. When comparing the course of both curves, as expected, the presence of the amphoter water generally increases the share of the cooperative mechanism. The ratio of $D_{\mathrm{H}^{+} \text {,coop }}$ to $D_{\mathrm{H}^{+}}$ reaches a value of $82 \%$ in a sample with a stoichiometry of $x=0.65$ and $6 \mathrm{wt} \%$ water content. Corresponding to the chemical shift in the ${ }^{1} \mathrm{H}$-NMR spectrum, the ratio relates to the ability of the protons to be delocalized on the NMR timescale and thus to participate in intermolecular transfer. A higher share of cooperative transport generally leads to a lower field of the chemical shift, as discussed above. In the case of the high acidic PIL [2-Sema][TfO], due to the similar acidity of [2-Sema $]^{+}$ and $\mathrm{H}_{3} \mathrm{O}^{+}$, the neutral MTau and $\mathrm{H}_{2} \mathrm{O}$ can both act as proton acceptors. The excess proton acceptors provide more sites for proton hopping, which accelerate the cooperative proton transport mechanism.

\section{Conclusion}

$N$-Methyltaurine and $\mathrm{TfOH}$ were mixed at various molar ratios in order to obtain samples of the proton-conducting liquid [2Sema][TfO] with various amounts of excess free acid $\mathrm{TfOH}$ or excess free base $N$-methyltaurine. The "nearly neat" samples and the samples with $6 \mathrm{wt} \%$ residual water were investigated regarding proton conductivity and self-diffusion using electrochemical and NMR methods. It could be observed that an excess of the free base MTau retards the vehicular proton transport due to an increase in the dynamic viscosity, which leads macroscopically to a lower (total) conductivity. Due to a comparable acidity of the cation [2-Sema $]^{+}$and the hydroxonium cation $\mathrm{H}_{3} \mathrm{O}^{+}$, an excess of MTau or $\mathrm{H}_{2} \mathrm{O}$ will enhance the fast proton exchange reactions between the $[2-\mathrm{Sema}]^{+}$cation, $\mathrm{H}_{3} \mathrm{O}^{+}$, MTau and $\mathrm{H}_{2} \mathrm{O}$ and thus will increase the share of cooperative transport.

In an PEFC electrolyte, based on a PIL immobilised in a polymer matrix, the proton conductivity depends on the presence and the share of cooperative transport as vehicular transport is significantly hampered. The use of a base-excess high acidic PIL would allow a higher fraction of cooperative transport and thus a higher proton conductivity. For the future use as conductive electrolytes in PEFCs at elevated operation temperatures $\left(100-120^{\circ} \mathrm{C}\right)$ and atmospheric (non-humidified) operation, a PIL with a high hygroscopicity to retain $\mathrm{H}_{2} \mathrm{O}$ formed during operation at the cathode and an excess of the base may be favorable. Enabling fast cooperative transport may help in reaching sufficient proton conductivities.

\section{Conflicts of interest}

There are no conflicts to declare.

\section{Acknowledgements}

This work is partially supported by the China Scholarship Council (Grant No. 201706060187). We are thankful to C. Wood for proofreading the manuscript.

\section{References}

1 Y. Liu, W. Lehnert, H. Janßen, R. C. Samsun and D. Stolten, J. Power Sources, 2016, 311, 91-102.

2 D. J. Jones and J. Rozière, J. Membr. Sci., 2001, 185, 41-58.

3 E. Quartarone and P. Mustarelli, Energy Environ. Sci., 2012, 5, 6436-6444.

4 Q. Li, J. O. Jensen, R. F. Savinell and N. J. Bjerrum, Prog. Polym. Sci., 2009, 34, 449-477.

5 J. A. Asensio, E. M. Sánchez and P. Gómez-Romero, Chem. Soc. Rev., 2010, 39, 3210-3239.

6 L. Vilčiauskas, M. E. Tuckerman, G. Bester, S. J. Paddison and K.-D. Kreuer, Nat. Chem., 2012, 4, 461.

7 C. Korte, F. Conti, J. Wackerl, P. Dams, A. Majerus and W. Lehnert, J. Appl. Electrochem., 2015, 45, 857-871.

8 K. Wippermann, J. Wackerl, W. Lehnert, B. Huber and C. Korte, J. Electrochem. Soc., 2015, 163, F25-F37.

9 K. Hsueh, E. Gonzalez and S. Srinivasan, Electrochim. Acta, 1983, 28, 691-697.

10 K. L. Hsueh, E. Gonzalez, S. Srinivasan and D. T. Chin, J. Electrochem. Soc., 1984, 131, 823-828.

11 B. R. Scharifker, P. Zelenay and J. M. Bockris, J. Electrochem. Soc., 1987, 134, 2714.

12 A. Noda, M. A. B. H. Susan, K. Kudo, S. Mitsushima, K. Hayamizu and M. Watanabe, J. Phys. Chem. B, 2003, 107, 4024-4033.

13 M. A. B. H. Susan, T. Kaneko, A. Noda and M. Watanabe, J. Am. Chem. Soc., 2005, 127, 4976-4983.

14 M. M. Mannarino, D. S. Liu, P. T. Hammond and G. C. Rutledge, ACS Appl. Mater. Interfaces, 2013, 5, 81558164.

15 D. E. Smith and D. A. Walsh, Adv. Energy Mater., 2019, 9, 1900744.

16 L. Koók, B. Kaufer, P. Bakonyi, T. Rózsenberszki, I. Rivera, G. Buitrón, K. Bélafi-Bakó and N. J. Nemestóthy, J. Membr. Sci., 2019, 570, 215-225.

17 J. Escorihuela, A. Garcia-Bernabe, A. Montero, O. Sahuquillo, E. Gimenez and V. Compan, Polymers, 2019, 11, 732.

18 J. Luo, A. H. Jensen, N. R. Brooks, J. Sniekers, M. Knipper, D. Aili, Q. Li, B. Vanroy, M. Wübbenhorst, F. Yan, L. Van 
Meervelt, Z. Shao, J. Fang, Z.-H. Luo, D. E. De Vos, K. Binnemans and J. Fransaer, Energy Environ. Sci., 2015, 8, 1276-1291.

19 P. Zelenay, B. Scharifker, J. M. Bockris and D. Gervasio, J. Electrochem. Soc., 1986, 133, 2262-2267.

20 V. S. Murthi, R. C. Urian and S. Mukerjee, J. Phys. Chem. B, 2004, 108, 11011-11023.

21 S. Liu, L. Zhou, P. Wang, F. Zhang, S. Yu, Z. Shao and B. Yi, ACS Appl. Mater. Interfaces, 2014, 6, 3195-3200.

22 S.-Y. Lee, A. Ogawa, M. Kanno, H. Nakamoto, T. Yasuda and M. Watanabe, J. Am. Chem. Soc., 2010, 132, 9764-9773.

23 H. Nakamoto, A. Noda, K. Hayamizu, S. Hayashi, H.-o. Hamaguchi and M. Watanabe, J. Phys. Chem. C, 2007, 111, 1541-1548.

24 M. L. Hoarfrost, M. Tyagi, R. A. Segalman and J. A. Reimer, J. Phys. Chem. B, 2012, 116, 8201-8209.
25 J. Lin, L. Wang, T. Zinkevich, S. Indris, Y. Suo and C. Korte, Phys. Chem. Chem. Phys., 2020, 22, 1145-1153.

26 K. D. Kreuer, A. Rabenau and W. Weppner, Angew. Chem., Int. Ed. Engl., 1982, 21, 208-209.

27 K. Wippermann, J. Giffin and C. Korte, J. Electrochem. Soc., 2018, 165, H263-H270.

28 P. Rimmelin, S. Schwartz and J. Sommer, Org. Magn. Reson., 1981, 16, 160-163.

29 P. Batamack and F. Jacques, Catal. Lett., 1995, 35, 135-142.

30 E. J. King, J. Am. Chem. Soc., 1953, 75, 2204-2209.

31 H. Huang, J. Y. Jin, J. H. Hong, J. S. Kang and W. Lee, Bull. Korean Chem. Soc., 2009, 30, 2827-2829.

32 M. Endres, J. Giffin and C. Korte, RSC Adv., submitted.

33 A. Kitada, S. Takeoka, K. Kintsu, K. Fukami, M. Saimura, T. Nagata, M. Katahira and K. Murase, J. Electrochem. Soc., 2018, 165, H121-H127. 